\title{
CAGAR BUDAYA CANDI BOROBUDUR SEBAGAI LABORATORIUM PENDIDIKAN
}

\author{
Nahar Cahyandaru
}

\begin{abstract}
Abstrak
Candi Borobudur merupakan monumen yang sangat fenomenal dan menjadi simbol kebesaran bangsa Indonesia. Borobudur mengandung nilai-nilai estetika, budaya, seni, arsitektur, hingga spiritual yang tinggi. Borobudur sebagai warisan dunia menyimpan sejuta mutiara yang dapat dipetik untuk modal pembangunan bangsa. Salah satunya adalah potensi Borobudur sebagai sarana pendidikan. Borobudur memberikan bekal masa depan anak cucu melalui nilai-nilai yang terkandung didalamnya. Potensi ilmu pengetahuan yang ada di situs Borobudur dan sekitarnya sangat kaya sehingga dapat diarahkan untuk pengembangan sarana pendidikan. Perubahan nama taman purbakala menjadi taman wisata sedikit banyak menyebabkan perubahan muatan pendidikan di dalamnya, apalagi dengan bentuk institusi sebagai perseroan terbatas. Potensi pendidikan di Borobudur masih sangat menarik untuk dikembangkan, terutama kawasan zona 1 yang saat ini pengelolaannya menjadi tanggung jawab Balai Konservasi Peninggalan Borobudur.
\end{abstract}

\section{Kata Kunci: Cagar Budaya, Candi Borobudur, Laboratorium Pendidikan}

\section{Pendahuluan}

Borobudur adalah sebuah monumen yang sangat fenomenal dan menjadi simbol kebesaran bangsa Indonesia. Keagungan Borobudur bagaimanapun sulit dinilai karena tingginya nilai-nilai estetika, budaya, seni, arsitektur, hingga spiritual. Dahulu di sekolah-sekolah diajarkan bahwa Borobudur adalah salah satu dari tujuh keajaiban dunia. Meskipun sekarang ada kriteria resmi Borobudur sebagai warisan dunia, predikat tujuh keajaiban dunia seolah-olah tidak bisa dipisahkan dari Borobudur.

\begin{abstract}
Kurangnya pemahaman masyarakat akan warisan dunia menyebabkan seolah-olah tujuh keajaiban dunia adalah parameter sah untuk mengukur keagungan Borobudur. Sehingga masyarakat begitu terkejut ketika mendengar kabar Candi Borobudur telah dikeluarkan dari tujuh keajaiban dunia. Pengumuman The New Seven Wonder oleh sebuah yayasan yang dipelopori Bernard Webber dari Swiss tidak mencantumkan Borobudur di dalamnya.

Sebenarnya informasi tidak masuknya Borobudur sebagai nominasi sudah diketahui sejak awal tahun 2007. Berbagai tanggapan
\end{abstract}

*Nahar Cahyandaru adalah Koordinator Kelompok Kerja Pemeliharaan Balai Konservasi Peninggalan Borobudur 
muncul saat itu, terutama yang mempertanyakan kriteria dan metode pemilihannya. Pemilihan dengan sistem pooling internet dan telepon internasional sangat merugikan negara-negara berkembang yang jauh dari hiruk pikuk penyelenggaraan pemilihan. Kriteria yang tidak jelas juga menyebabkan hasil pemilihan yang hanya sesuai dengan selera pemilih saja. Singkat kata, proses itu hanya menyerupai pemilihan bintang idol di televisi. Pemenang belum tentu yang terbaik, tapi yang mampu menggalang dukungan dengan berbagai cara.

Tujuh keajaiban dunia sendiri merupakan parameter yang abstrak. Bahkan, pada hari pengumuman itu UNESCO segera mempertanyakan kegiatan pemilihan tersebut. Predikat tujuh keajaiban dunia seperti sebuah legenda dengan banyak versi. Pada zaman Romawi kuna telah dikenal tujuh keajaiban dunia, tentu saja Borobudur belum masuk didalamnya. Berbagai sumber juga banyak memberikan versi yang beragam tentang apa saja yang disebut keajaiban dunia. Berbagai versi tersebut ada yang memasukkan Borobudur ada juga yang tidak, sebagian yang lain memasukkan
Borobudur dalam keajaiban dunia yang terlupakan.

Hingga saat ini tidak ada lembaga resmi yang secara khusus mengelola predikat tujuh keajaiban dunia dengan kriteria-kriterianya. Pengumuman yang terakhir ini juga hanya akan menambah versi dari berbagai versi yang telah ada. Gaung pengumuman tersebut demikian besar karena diumumkan pada tanggal "keramat" 07-07-07 (7 Juli 2007). Lantas jika demikian, siapa yang dapat melarang jika kita tetap menyebut Borobudur sebagai keajaiban dunia.

Satu hal yang kurang tersosialisasi di masyarakat adalah telah diakuinya Borobudur sebagai salah satu warisan dunia, ditetapkan dalam World Herritage List nomor 592 tahun 1991 oleh UNESCO. Kriteria world heritage sangat jelas dan melalui proses penilaian yang panjang. Situs yang telah masuk dalam daftar warisan dunia juga dimonitor secara terus-menerus untuk mengevaluasi pengelolaannya. Kriteria warisan dunia merupakan kriteria resmi yang dikeluarkan UNESCO sebagai organisasi dibawah PBB. Situs yang masuk dalam daftar warisan dunia telah melalui proses 
penilaian yang panjang dan ketat dengan parameter-parameter yang terukur. Saat ini Indonesia memiliki tiga situs yang telah ditetapkan sebagai warisan dunia untuk kategori budaya, yaitu Borobudur, Prambanan, dan Sangiran. Selain itu beberapa situs juga tengah diajukan, antara lain rumah adat Toraja dan Puri Taman Ayung Mengwi di Bali.

Permasalahan yang dihadapi saat ini adalah kurangnya pemahaman masyarakat akan pengakuan warisan dunia ini. Tidak banyak masyarakat yang mengetahui bahwa Borobudur telah diakui secara Internasional sebagai warisan dunia. Masyarakat lebih mengenal Borobudur sebagai tujuh keajaiban dunia, bukan sebagai warisan dunia. Ketika muncul versi baru tujuh keajaiban dunia yang tidak memasukkan Borobudur, masyarakat begitu gempar. Kampanye Borobudur sebagai warisan dunia menjadi semakin mendesak untuk dilakukan, agar dapat memberikan pemahaman yang benar tentang warisan dunia. Buku-buku pelajaran sejarah juga perlu mencantumkan pengertian warisan dunia dan situs-situs di Indonesia yang telah diakui.
Kampanye warisan dunia juga diperlukan bagi pengembangan situs-situs lain yang berpotensi untuk masuk dalam daftar warisan dunia. Indonesia sangat kaya dengan sumber daya budaya yang layak mendapat pengakuan sebagai warisan dunia. Daerah-daerah yang memiliki potensi warisan dunia perlu digugah kesadarannnya untuk meningkatkan pengelolaan kekayaan budayanya. Situs yang masuk dalam daftar warisan dunia menjadi situs "milik" dunia, sehingga setiap permasalahan yang dihadapi menjadi tanggung jawab dunia melalui UNESCO sebagai pengelola. Sebagai contoh penanganan candi Prambanan pasca kerusakan akibat gempa, UNESCO dan negara-negara anggotanya turut memberikan bantuan. UNESCO juga memberikan bantuan pengelolaan situs dalam bentuk pendampingan dan bantuan peralatan jika dibutuhkan. Sebagai konsekuensinya, situs yang telah masuk dalam daftar warisan dunia harus dikelola secara professional sesuai dengan standar pengelolaan warisan dunia.

Tantangan yang dihadapi institusi pengelola Borobudur adalah mempertahankan kelestarian Borobudur dan lingkungannya sesuai 
standar pengelolaan warisan dunia.

Kelestarian Borobudur tidak hanya pada candinya saja, namun juga lingkungannya sebagai satu kesatuan lanskap. Hal ini menuntut berbagai pihak turut mendukung upaya yang dilakukan, termasuk masyarakat. Pelestarian kawasan Borobudur mustahil jika hanya dilakukan oleh satu pihak saja.

Masyarakat juga perlu berpartisipasi secara aktif dengan turut menjaga kelestarian Borobudur. Masih banyak perilaku masyarakat yang perlu dibenahi ketika berkunjung ke Borobudur, salah satunya adalah kebersihan. Perilaku membuang sampah pada tempatnya belum menjadi kesadaran budaya sebagian masyarakat kita. Padahal sampah yang dibuang di lingkungan candi, terutama makanan dapat berdampak buruk bagi pelapukan batu candi. Masyarakat sekitar Borobudur juga harus mendukung upaya pelestarian dengan memberikan kenyamanan bagi setiap pengunjung Borobudur.

\section{Balai}

Konservasi

Peninggalan Borobudur telah menggalakkan kampanye tersebut, salah satunya dengan dilaksanakannya diklat pengelolaan warisan dunia. Berbagai pemangku kepentingan diundang sebagai peserta untuk menghasilkan pemahaman bersama yang komprehensip. Gaung diklat tersebut begitu kuat karena mendatangkan pembicara tingkat nasional dan Internasional serta mengundang peserta dari seluruh Indonersia. Outcome yang diharapakan ternyata segera dapat dilihat. Salah satunya adalah mulai dicantumkannya keterangan warisan dunia oleh PT. Taman Wisata Candi Borobudur Prambanan dan Ratu Boko. Keterangan tersebut dapat dilihat pada petunjuk arah mulai dari jalan Jogja-Magelang, papan nama di pintu masuk wisata, hingga ke lembaran tiket masuk wisatawan. Berbagai pihak juga diharapkan dapat mendukung kampanye tersebut dengan berbagai cara yang sesuai dengan tanggung jawab pekerjaannya. Jika semua instansi yang bertanggung jawab pada pelestarian dan pemanfaatan Borobudur bekerja secara optimal, didukung oleh peran serta masyarakat, predikat warisan dunia akan tetap disandang. Meskipun tanpa embel-embel apapun keagungan Borobudur akan tetap melekat, namun predikat warisan 
dunia merupakan pengakuan resmi internasional yang harus kita jaga. Visi pelestarian yang senantiasa dipegang oleh institusi pelestari Borobudur adalah mewujudkan kelestarian Borobudur sebagai warisan dunia. Lebih lanjut predikat warisan dunia yang telah susah payah diraih dan dipertahankan akan tidak bermakna jika masyarakat Indonesia sebagai "pemilik" Borobudur justru tidak mengetahuinya.

\section{Karya Agung Nenek Moyang}

Borobudur sebagai monumen karya nenek moyang yang agung menjadi kebanggan bangsa Indonesia dan telah diakui dunia. Keagungan Borobudur bagaimanapun sulit dinilai karena tingginya nilainilai estetika, budaya, seni, arsitektur, hingga spiritual. Pengakuan dunia telah ditetapkan dalam predikat warisan dunia (World Heritage) oleh UNESCO No. 592 tahun 1991. Kriteria warisan dunia merupakan predikat yang resmi dan melalui tahap penilaian yang panjang. Situs yang masuk warisan dunia juga terusmenerus dievaluasi dan dimonitor oleh UNESCO.
Warisan dunia merupakan kriteria resmi oleh dunia internasional sehingga perlu disosialisaikan secara luas. Dahulu di sekolah-sekolah diajarkan bahwa Borobudur adalah salah satu dari tujuh keajaiban dunia. Meskipun sekarang ada kriteria resmi Borobudur sebagai warisan dunia, predikat tujuh keajaiban dunia seolah-olah tidak bisa dipisahkan dari Borobudur. Diperlukan upaya-upaya sosialisasi terus-menerus kepada masyarakat bahwa pengakuan internasional terhadap Borobudur adalah dalam bentuk warisan dunia, bukan sebagai tujuh keajaiban dunia. Karena tujuh keajaiban dunia merupakan ukuran yang tidak resmi dan banyak versi, bahkan cenderung sebagai mitos. Bahkan, tujuh keajaiban dunia versi pertama (zaman Romawi kuna) sebagian sudah tidak ada lagi, sehingga kemudian muncul berbagai versi.

Pengumuman The New Seven Wonder pada tanggal keramat 07-07-07 yang dipilih melalui pooling internet hanya akan menambah versi, dari berbagai versi yang telah ada. Singkat kata, predikat tujuh keajaiban dunia merupakan kriteria yang tidak dapat dijadikan pedoman dalam 
mengukur keagungan Borobudur.

Sebaliknya warisan dunia yang resmi dikeluarkan oleh UNESCO sebagai sebuah lembaga internasional di bawah PBB, menjadi penting untuk terus disosialisasikan.

\section{Borobudur ditetapkan}

sebagai warisan dunia tahun 1991 dengan nomor 592 setelah melalui proses penilaian yang panjang. Borobudur bisa ditetapkan karena mempunyai "Outstanding universal value" atau nilai universal yang luar biasa. Outstanding universal value adalah signifikansi (makna penting) budaya dan/ atau alam yang sangat luar biasa sehingga melampaui batas nasional dan memiliki arti penting bagi generasi sekarang maupun mendatang dari semua umat manusia.

UNESCO menetapkan enam kriteria Outstanding universal value, suatu situs dapat ditetapkan sebagai warisan dunia. Kriteria tersebut adalah sebagai berikut : (i) Mewakili suatu mahakarya (masterpiece) kejeniusan kreatif manusia;

(ii) Menunjukkan pentingnya pertukaran nilai-nilai kemanusiaan, dalam suatu rentang waktu atau dalam suatu kawasan budaya di dunia, dalam pengembangan arsitektur atau teknologi, karya monumental, tata kota atau desain lanskap;

(iii) Memiliki keunikan atau sekurang-kurangnya pengakuan luar biasa terhadap tradisi budaya atau peradaban yang masih berlaku maupun yang telah hilang/ punah;

(iv) Merupakan contoh luar biasa dari suatu jenis bangunan, arsitektural atau himpunan teknologi atau lanskap yang menggambarkan tahapan penting dalam sejarah manusia;

(v) Merupakan contoh luar biasa tentang pemukiman tradisional manusia, tata-guna tanah, atau tata-guna kelautan yang menggambarkan interaksi budaya (atau berbagai budaya), atau interaksi manusia dengan lingkungan, terutama ketika pemukiman tersebut menjadi rentan karena dampak perubahan yang menetap (irreversible)

(vi) Secara langsung atau nyata dikaitkan dengan peristiwa atau tradisi yang berlaku, dengan gagasan, atau dengan keyakinan, dengan karya seni dan sastra yang memiliki nilai universal 
yang signifikan (komite menganggap bahwa kriteria ini lebih baik digabungkan dengan kriteria lain)

Borobudur dinilai oleh UNESCO memenuhi kriterian (i), (ii), dan (vi).

Candi Borobudur terletak di Desa Borobudur, Kecamatan Borobudur, Kabupaten Magelang, Propinsi Jawa Tengah. Secara astronomis terletak di $7^{\circ} 36^{\prime} 28^{\prime \prime} \mathrm{LS}$ dan $110^{\circ} 12^{\prime} 13^{\prime \prime}$ BT. Lingkungan geografis Candi Borobudur dikelilingi oleh Gunung Merapi dan Merbabu di sebelah Timur, Gunung Sindoro dan Sumbing di sebelah Utara, dan pegunungan Menoreh di sebelah Selatan, serta terletak di antara Sungai Progo dan Elo. Candi Borobudur didirikan di atas bukit yang telah dimodifikasi, dengan ketinggian $265 \mathrm{dpl}$.

Denah Candi Borobudur ukuran panjang 121,66 meter dan lebar 121,38 meter. Tinggi 35,40 meter. Susunan bangunan berupa 9 teras berundak dan sebuah stupa induk di puncaknya. Terdiri dari 6 teras berdenah persegi dan3 teras berdenah lingkaran. Pembagian vertikal secara filosofis meliputi tingkat Kamadhatu, Rupadhatu, dan
Arupadhatu. Pembagian vertikal secara teknis meliputi bagian bawah, tengah, dan atas. Terdapat tangga naik di keempat penjuru utama dengan pintu masuk utama sebelah timur dengan ber-pradaksina.Batubatu Candi Borobudur berasal dari sungai di sekitar Borobudur dengan volume seluruhnya sekitar 55.000 meter kubik (kira-kira 2.000.000 potong batu).

Candi Borobudur muncul kembali tahun 1814 ketika Sir Thomas Stanford Raffles, Gubernur Jenderal Inggris yang menjadi wali negara Indonesia mengadakan kegiatan di Semarang, waktu itu Raffles mendapatkan informasi bahwa di daerah Kedu telah ditemukan susunan batu bergambar, kemudian ia mengutus Cornelius seorang Belanda untuk membersihkannya. Pekerjaan ini dilanjutkan oleh Residen Kedu yang bernama Hartman pada tahun 1835. Disamping kegiatan pembersihan, ia juga mengadakan penelitian khususnya terhadap stupa puncak Candi Borobudur, namun sayang mengenai laporan penelitian ini tidak pernah terbit. Pendokumentasian berupa gambar bangunan dan relief candi dilakukan oleh Wilsen selama 4 tahun sejak 
tahun 1849 , sedangkan dokumen foto dibuat pada tahun 1873 oleh Van Kinsbergen. Menurut legenda Candi Borobudur didirikan oleh arsitek Gunadharma, namun secara historis belum diketahui secara pasti. Pendapat Casparis berdasarkan interpretasi prasasti berangka tahun 824 M dan prasasti Sri Kahulunan 842 M, pendiri Candi Borobudur adalah Smaratungga yang memerintah tahun 782-812 M pada masa dinasti Syailendra. Candi Borobudur dibangun untuk memuliakan agama Budha Mahayana.

Pendapat Dumarcay Candi Borobudur didirikan dalam 5 tahap pembangunan yaitu:

- Tahap I + 780 Masehi

- Tahap II dan III + 792 Masehi

- Tahap IV + 824 Masehi

- Tahap V + 833 Masehi

Mengenai penamaannya juga terdapat beberapa pendapat. Menurut Raffles berasal dari kata Budur yang kuno (Boro $=$ kuno, budur $=$ nama tempat) Sang Budha yang agung (Boro= agung, budur= Buddha) Budha yang banyak (Boro= banyak, budur= Buddha). Menurut Moens, borobudur berarti kota para penjunjung tinggi Sang Budha. Menurur Casparis berasal dari kata sang kamulan ibhumisambharabudara, berdasarkan kutipan dari prasasti Sri Kahulunan 842 M yang artinya bangunan suci yang melambangkan kumpulan kebaikan dari kesepuluh tingkatan Bodhisattva. Menurut Poerbatjaraka berasal dari kata Biara di Budur (Budur= nama tempat/desa). Adapun menudur Soekmono dan Stutertheim berasal dari kata Bara dan budur berarti biara di atas bukit Menurut Soekmono fungsi Candi Borobudur sebagai tempat ziarah untuk memuliakan agama Budha aliran Mahayana dan pemujaan nenek moyang.

\section{Relief Candi}

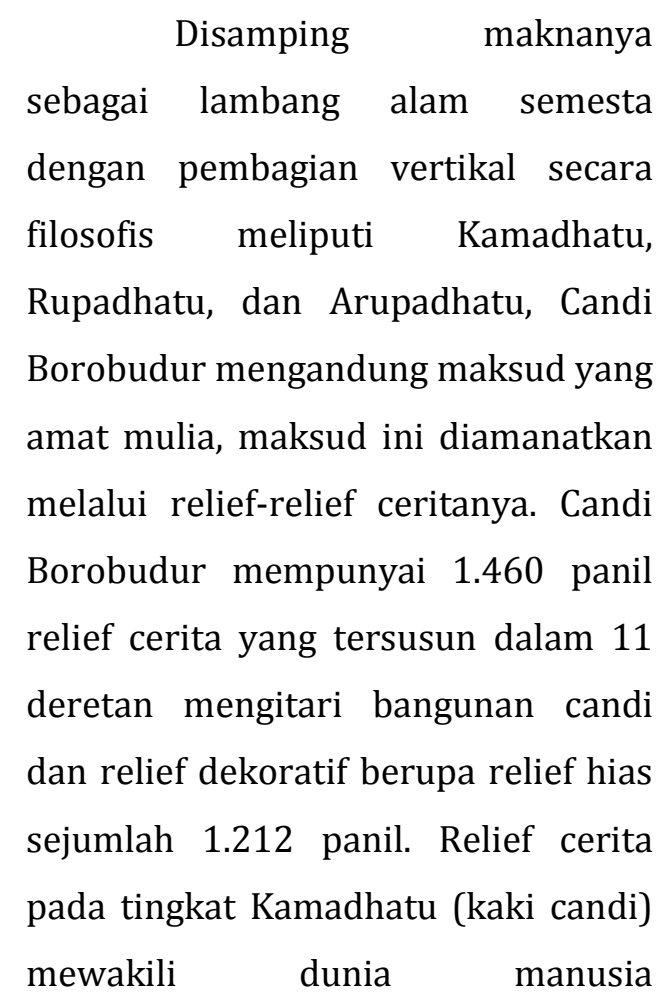


menggambarkan perilaku manusia yang masih terikat oleh nafsu duniawi. Hal ini terlihat pada dinding kaki candi yang asli terpahatkan 160 panil relief Karmawibhangga yang menggambarkan hukum sebab akibat. Tingkat Rupadhatu (badan candi) mewakili dunia antara, menggambarkan perilaku manusia yang sudah mulai meninggalkan keinginan duniawi, akan tetapi masih terikat oleh suatu pengertian dunia nyata. Pada tingkatan ini dipahatkan 1.300 panil yang terdiri dari relief Lalitavistara, Jataka, Avadana, dan Gandawyuha. Berikut uraian singkat dari relief tersebut:

\section{Tingkat I}

Dinding atas relief Lalitavistara 120 panil. Relief ini menggambarkan riwayat hidup Sang Buddha Gautama dimulai pada saat para dewa di surga Tushita mengabulkan ermohonan Bodhisattva untuk turun ke dunia menjelma menjadi manusia bernama Buddha Gautama. Ratu Maya sebelum hamil bermimpi menerima kehadiran gajah putih dirahimnya. Di Taman Lumbini Ratu Maya melahirkan puteranya dan diberi nama pangeran Sidharta. Pada waktu lahir Sidharta sudah dapat berjalan, dan pada tujuh langkah pertamanya tumbuh bunga teratai. Setelah melahirkan Ratu Maya meninggal, dan Sidharta diasuh oleh bibinya Gautami. Setelah dewasa Sidharta kawin dengan Yasodhara yang disebut dengan dewi Gopa.

Dalam suatu perjalanan Sidharta mengalami empat perjumpaan yaitu bertemu dengan pengemis tua yang buta, orang sakit, orang mati membuat Sidharta menjadi gelisah, karena orang dapat menjadi tua, menderita, sakit dan mati. Akhirnya Sidharta bertemu dengan seorang pendeta, wajah pendeta itu damai, umur tua, sakit, dan mati tidak menjadi ancaman bagi seorang pendeta. Oleh karena menurut ramalan Sidharta akan menjadi pendeta, maka ayahnya mendirikan istana yang megah untuk Sidaharta.

Setelah mengalami empat perjumpaan tersebut Sidharta tidak tenteram tinggal di istana, akhirnya diam-diam meninggalkan istana. Sidharta memutuskan enjadi pendeta dengan memotong rambutnya. Pakaian istana ditinggalkan dan memakai pakaian budak yang sudah meninggal, dan bersatu dengan orangorang miskin. Sebelum melakukan samadi Sidharta mensucikan diri di 
sungai Nairanjana. Sidharta senang ketika seorang tukang rumput mempersembahkan tempat duduk dari rumput usang. Di bawah pohon Bodhi pada waktu bulan purnama di bulan Waisak, Sidharta menerima pencerahan sejati, sejak itu Sidharta menjadi Buddha di kota Benares.

Dinding bawah relief Manohara dan Avadana 120 panil Cerita Manohara menggambarkan cerita udanakumaravada yaitu kisah perkawinan pangeran Sudana dengan bidadari Manohara. Karena berjasa menyelamatkan seekor naga, seorang pemburu bernama Halaka mendapat hadiah laso dari orang tua naga. Pada suatu hari Halaka melihat bidadari mandi di kolam, dengan lasonya berhasil menjerat salah seorang bidadari tercantik bernama Manohara. Oleh karena Halaka tidak sepadan dengan Manohara, maka Manohara dipersembahkan kepada pangeran Sudana, meskipun ayah Sudana tidak setuju. Banyaknya rintangan tidak dapat menghalangi pernikahan pangeran Sudana dengan Manohara. Cerita Awadana mengisahkan penjelmaan kembali orang-orang suci, diantaranya kisah kesetiaan raja Sipi terhadap makhluk yang lemah. Seekor burung kecil minta tolong raja Sipi agar tidak dimangsa burung elang. Sebaliknya burung elang minta raja Sipi menukar burung kecil dengan daging raja Sipi. Setelah ditimbang ternyata berat burung kecil dengan raja Sipi sama beratnya, maka raja Sipi bersedia mengorbankan diri dimangsa burung elang. Seorang pemimpin harus berani mengorbankan dirinya untuk rakyat kecil dan semua makhluk hidup.

Langkan bawah (kisah binatang) relief Jatakamala 372 panil, langkan atas (kisah binatang) relief Jataka128 panil. Relief ini mempunyai arti untaian cerita jataka yang mengisahkan reinkarnasi sang Buddha sebelum dilahirkan sebagai seorang manusia bernama pangeran Sidharta Gautama. Kisah ini cenderung pada penjelmaan sang Buddha sebagai binatang yang berbudi luhur dengan pengorbanannya. Cerita jataka diantaranya kisah kera dan banteng. Kera yang nakal suka mengganggu banteng, namun banteng diam saja. Dewi hutan menasehati banteng untuk melawan kera, namun banteng menolak mengusir kera karena takut kera akan pergi dari hutan dan mengganggu kedamaian binatang- 
binatang lain. Akhirnya dewi hutan bersujud kepada banteng karena sikap banteng didalam menjaga keserasian dan kedamaian di hutan. Kisah jataka lainnya adalah pengorbanan seekor gajah yang mempersembahkan dirinya untuk dimakan oleh para pengungsi yang kelaparan.

\section{Tingkat II}

Dinding relief Gandawyuha 128 panil. Langkan relief Jataka/Avadana 100 panil Relief ini mungkin melanjutkan kehidupan Sang Buddha di masa lalu. Beberapa adegan dikenal kembali antara lain terdapat pada sudut barat laut, yaitu Bodhisattva menjelma sebagai burung merak dan tertangkap, akhirnya memberikan ajarannya.

\section{Tingkat III}

Dinding relief Gandawyuha 88 panil. Relief ini menggambarkan riwayat Bodhisattva Maitreya sebagai calon Budha yang akan datang, merupakan kelanjutan dari cerita di tingkat II.

Tokoh yang diarcakan adalah: Dhyani Buddha, Manusi Buddha, dan Boddhisatva. Jumlah arca sebanyak 504 buah. Rincian letak arca sebagai berikut:
- Pada tingkat Rupadhatu terdapat 432 arca, ukuran semakin ke atas semakin kecil dan diletakkan pada relung, dengan rincian: Teras I : 104 arca Teras II : 104 arca Teras III : 88 arca Teras IV : 72 arca Teras $\mathrm{V}: 64$ arca

- Pada tingkat Arupadhatu terdapat 72 arca dengan ukuran sama dan diletakkan di dalam stupa, dengan rincian:Teras VI : 32 arca Teras VII : 24 arca Teras VIII : 16 arca

- Pada tingkat Rupadhatu ini terdapat 432 arca Dyani Buddha diletakkan di dalam relung di segala penjuru arah mata angin yaitu: Arca Dhyani Buddha Aksobya letak di sisi Timur dengan sikap tangan Bhumisparsamudra, Arca Dhyani Buddha Ratnasambhawa letak sisi Selatan dengan sikap tangan Waramudra, Arca Dhyani Buddha Amoghasidha letak di sisi Utara dengan sikap tangan Abhayamudra, Arca Dhyani Buddha Wairocana di pagar langkan tingkat $\mathrm{V}$ dengan sikap Witarkamudra.

- Di dalam stupa teras I, II, dan III terdapat arca Dhyani Buddha Vajrasattva dengan sikap tangan Dharmacakramudra 
- Arca singa : 32 buahMenurut agama Buddha singa adalah kendaraan sang Buddha pada waktu naik ke surga, simbol kekuatan pengusir pengaruh jahat untuk menjaga kesucian Candi Borobudur.

Jumlah stupa 73 buah dengan rincian 1 buah stupa induk, 32 stupa pada teras melingkar I, 24 stupa pada teras melingkar II, dan 16 stupa pada teras melingkar III. Bentuk stupa sebagai berikut adalah stupa induk berongga, tanpa lubang terawang dan stupa pada teras melingkar berlubang terawang:Lubang belah ketupat pada stupa teras melingkar I dan II Lubang segi empat pada stupa teras melingkar III. Arti simbolis lubang terawang belah ketupat: Berkaitan dengan filosofi menuju ke tingkat kesempurnaan. Arti simbolis lubang terawang segi empat: Berkaitan dengan filosofi lebih sederhana atau ?sempurna? daripada bentuk belah ketupat yang masih tergolong raya.

\section{Pemugaran Candi}

Upaya pemugaran Candi Borobudur dilakukan sebanyak dua kali yaitu pertama dilakukan oleh pemerintah Hindia Belanda dibawah pimpinan Van Erp dan yang kedua dilakukan oleh pemerintah Indonesia yang diketuai oleh Soekmono (alm).

Pemugaran I tahun 1907 -

1911, Pemugaran I sepenuhnya dibiayai oleh pemerintah Hindia Belanda. Sasaran pemugaran lebih banyak ditujukan pada bagian puncak candi yaitu tiga teras bundar dan stupa pusatnya. Namun oleh karena beberapa batunya tidak diketemukan kembali, bagian puncak (catra) stupa, tidak bisa dipasang kembali. Pemugaran bagian bawahnya lebih bersifat tambal sulam seperti perbaikan/pemerataan lorong, perbaikan dinding dan langkan tanpa pembongkaran sehingga masih terlihat miring. Usaha-usaha konservasi telah dilakukan sejak pemugaran pertama oleh Pemerintah Hindia Belanda dengan terus menerus mengadakan pengamatan dan penelitian terhadap Candi Borobudur, sementara proses kerusakan dan pelapukan batu-batu Candi Borobudur yang disebabkan oleh berbagai faktor terus berlangsung. Dan hasil penelitian yang diadakan oleh suatu panitia yang dibentuk dalam tahun 1924 diketahui bahwa sebab-sebab kerusakan itu ada 3 macam, yaitu korosi, kerja mekanis dan kekuatan tekanan dan tegangan 
di dalam batu-batu itu sendiri (O.V. 1930 : 120-132).

Pemugaran II tahun 1973 1983, Sesudah usaha pemugaran Van Erp berhasil diselesaikan pada tahun 1911, pemeliharaan terhadap Candi Borobudur terus dilakukan. Berdasarkan perbandingan antara kondisi saat itu dengan foto-foto yang dibuat Van Erp 10 tahun sebelumnya, diketahui ternyata proses kerusakan pada Candi Borobudur terus terjadi dan semakin parah, terutama pada dinding relief batu-batunya rusak akibat pengaruh iklim. Selain itu bangunan candinya juga terancam oleh kerusakan. Dengan masuknya Indonesia menjadi anggota PBB, maka secara otomatis Indonesia menjadi anggota UNESCO. Melalui lembaga UNECO tersebut, Indonesia mulai mengimbau kepada dunia internasional untuk ikut menyelamatkan bangunan yang sangat bersejarah tersebut. Usaha tersebut berhasil, dengan dana dari Pelita dan dana UNESCO, pada tahun 1975 mulailah dilakukan pemugaran secara total. Oleh karena pada tingkat Arupadhatu keadaannya masih baik, maka hanya tingkat bawahnya saja yang dibongkar. Dalam pembongkaran tersebut ada tiga macam pekerjaan, yaitu tekno arkeologi yang terdiri atas pembongkaran seluruh bagian Rupadhatu, yaitu empat tingkat segi empat di atas kaki candi, pekerjaan teknik sipil yaitu pemasangan pondasi beton bertulang untuk mendukung Candi Borobudur untuk setiap tingkatnya dengan diberi saluran air dan lapisan kedap air di dalam konstruksinya, dan pekerjaan kemiko arkeologis yaitu pembersihan dan pengawetan batu-batunya, dan akhirnya penyusunan kembali batubatu yang sudah bersih dari jasad renik (lumut, cendawan, dan mikroorganisme lainnya) ke bentuk semula.

Candi Borobudur setelah selesai dipugar tidak berarti selesai sudah perawatan terhadap candi tersebut. Tidak ada jaminan kalau Candi Borobudur terbebas dari proses kerusakan dan pelapukan. Oleh karena itu kantor Balai Konservasi Borobudur selalu melakukan monitoring dan evaluasi secara berkesinambungan. Misalnya monitoring melalui kegiatan observasi pertumbuhan mikroorganisme, observasi stabilitas batu candi, evaluasi struktur candi dan buki, observasi geohydrologi, 
observasi sistem drainase, analisis mengenai dampak lingkungan, dan lain-lain.

$$
\text { Usaha perlindungan }
$$

dilakukan dengan membuat mintakat (zoning) pada situs Candi Borobudur yaitu:

- Zone I Area suci, untuk perlindungan monumen dan lingkungan arkeologis (radius 200 m)

- Zone II Zona taman wisata arkeologi, untuk menyediakan fasilitas taman dan perlindungan lingkungan sejarah (radius $500 \mathrm{~m}$ )

- Zone III Zona penggunaan tanah dengan aturan khusus, untuk mengontrol pengembangan daerah di sekitar taman wisata (radius 2 $\mathrm{km})$

- Zone IV Zona Perlindungan daerah bersejarah, untuk perawatan dan pencegahan kerusakan daerah sejarah (radius $5 \mathrm{~km}$ )

- Zone V Zona taman arkeologi nasional, untuk survei arkeologi pada daerah yang luas dan pencegahan kerusakan monumen yang masih terpendam (radius 10 $\mathrm{km})$.

Zona I dan zona II dimiliki oleh pemerintah. Zona I dikelola oleh Balai Studi dan Konservasi
Borobudur, zona II dikelola oleh PT Taman Wisata Candi Borobudur, Prambanan dan Ratu Boko. Pada zona II juga tersedia fasilitas turis : parkir mobil, loket tiket, pusat informasi, museum, kios-kios, dan lain-lain. Zona III, IV, dan V dimiliki oleh masyarakat, tetapi pemanfaatannya dikontrol oleh pemerintah daerah.

\section{Laboratorium Pendidikan}

$$
\text { Borobudur yang telah }
$$
ditetapkan sebagai warisan dunia menyimpan sejuta mutiara yang dapat dipetik untuk modal pembangunan bangsa. Salah satunya adalah potensi Borobudur sebagai sarana pendidikan. Motto Borobudur for children future yang pernah digaungkan, sesungguhnya bukan sekedar mewariskan sebuah benda bernama candi Borobudur kepada anak cucu. Tetapi untuk memberikan bekal masa depan anak cucu melalui nilai-nilai yang terkandung didalamnya.

$$
\text { Di sisi lain pendidikan }
$$
merupakan tanggung jawab penting Negara terhadap rakyat terutama untuk menyiapkan generasi mendatang yang lebih baik. Pendidikan selalu dipandang sebagai 
hal penting yang harus mendapatkan prioritas. Sistem pendidikan yang dikembangkan oleh pemerintah senantiasa diperbaharui untuk menciptakan model pembelajaran yang lebih baik. Sistem yang sedang berjalan saat ini adalah sistem KTSP (Kurikulum Tingkat Satuan Pendidikan) sebagai penyempurnaan system KBK (Kurikulum Berbasis Kompetensi). Pada sistem KBK peserta didik dituntut untuk lebih berinteraksi secara langsung dengan materi yang sedang dipelajari. Interaksi langsung tersebut diharapkan mampu memberikan pengetahuan yang lebih utuh, tidak sekedar pengetahuan yang bersifat normatif saja.

$$
\text { Sehingga KBK meliputi }
$$
pengembangan aspek normatif, afektif dan psikomotorik pada saat yang bersamaan ketika mempelajari suatu materi. Sebagai contoh pada pelajaran Biologi mengenai klasifikasi tumbuhan. Peserta didik tidak sekedar dijelaskan dari buku teks tentang klasifikasi tumbuhan, tetapi dibawa langsung ke lapangan untuk mengoservasi contoh-contoh tumbuhan dan mengklasifikasikannya. Dengan demikian peserta didik lebih memahami materi yang dipelajari, sekaligus mengasah aspek psikomotorik ketika melakukan observasi, dan aspek afektif untuk melestarikan alam.

Sistem ini menuntut model pembelajaran yang banyak terjun ke lapangan, sehingga diperlukan sarana-sarana pendidikan yang lebih kreatif. Pada sistem KTSP, model pembelajaran lebih berpotensi untuk dikembangkan karena kurikulum dikembangkan oleh masing-masing satuan pendidikan. Untuk mendukung hal tersebut diperlukan sarana pendidikan yang lebih luas, variatif, kreatif, dan berkualitas.

Potensi ilmu pengetahuan yang ada di situs Borobudur dan sekitarnya sangat kaya sehingga dapat diarahkan untuk pengembangan sarana pendidikan. Hal ini sesuai dengan fungsi Borobudur yang dicanangkan pada saat pemugaran oleh pemerintah Indonesia dan UNESCO. Berdasarkan Masterplan yang dibuat oleh JICA kawasan Borobudur akan dijadikan sebagai Taman Purbakala, sehingga proyek penataan kawasan Borobudur kala itu diberi nama TAPURNAS (Taman Purbakala Nasional). Taman ini akan berfungsi sebagai pusat 
pengembangan ilmu pengetahuan, pendidikan, pelatihan, disamping sebagai sarana rekreasi. Dalam perkembangannya berdasarkan Kepres didirikan sebuah perusahaan BUMN dalam bentuk PT. Taman Wisata Candi Borobudur, yang selanjutnya disatukan dengan Prambanan dan Ratu Boko. Perubahan nama taman purbakala menjadi taman wisata sedikit banyak menyebabkan perubahan muatan pendidikan di dalamnya, apalagi dengan bentuk institusi sebagai perseroan terbatas.

Namun potensi pendidikan di Borobudur masih sangat menarik untuk dikembangkan. Terutama kawasan zona 1 yang saat ini pengelolaannya menjadi tanggung jawab Balai Konservasi Peninggalan Borobudur. Balai Konservasi sebagai Unit Pelaksana Teknis di lingkungan Departemen Kebudayaan dan Pariwisata memiliki tugas pokok dan fungsi untuk melestarikan situs Borobudur, serta melakukan penelitian dan pengembangan.

Zona 1 meliputi candi borobudur dan kawasan di sekelilingnya seluas 44,8 hektar. Kawasan ini sangat berpotensi untuk dikembangkan sebagai sarana pendidikan. Beberapa bidang yang dapat dikemukakan di sini antara lain

1.Biologi

Pada area zona 1 tersimpan berbagai biota yang dapat diobservasi pada pembelajaran biologi. Jenis-jenis tanaman yang ada di sekitar candi sangat beragam dan unik, sebagian diantaranya merupakan tanaman langka. Tanaman-tanaman dan binatang asli Indonesia juga dapat diobservasi dari adegan-adegan pada setiap relief candi.

2. Kimia

Balai Konservasi sebagai penanggung jawab pengelolaan zona 1 memiliki fasilitas penelitian, salah satunya adalah laboratorium kimia yang dapat dijadikan sebagai sarana pembelajaran. Material candi dan sekitarnya juga dapat menjadi sampel kimia yang menarik untuk didiskusikan.

3. Geografi/Geologi

Borobudur terletak di atas bukit yang menimbulkan keunikan kontur lingkungannya. Pembelajaran mengenai kontur tanah, lingkungan geologis, termasuk lingkungan geologis kuna sangat menarik di lakukan di Borobudur.

4. Sejarah 
Tidak diragukan lagi bahwa data sejarah yang ada pada Borobudur sangat berlimpah. Pembelajaran sejarah Indonesia yang dilakukan di Borobudur dapat memberikan wawasan yang sangat luas.

\section{Bahasa}

Borobudur senantiasa dikunjungi oleh wisatawan, baik domestik maupun mancanegara yang berasal dari berbagai negara. Hal ini tentu saja menjadikan Borobudur sebagai sumber pembelajaran Bahasa yang sangat kaya. Setiap pengunjung Borobudur dapat menajdi narasumber pembelajaran bahasa, terutama wisatwan asing. Pembelajaran bahasa asing akan menemukan native speaker dengan mudah di Borobudur.

Bidang-bidang di atas hanya sebagian dari berbagai bidang yang masih sangat mungkin untuk dikembangkan. Borobudur masih menantikan sentuhan pada pemikir dan pelaku pendidikan untuk digarap sebagai laboratorium pendidikan.

\section{Daftar Pustaka}

Anom, IGN. 2005. The Restoration of Borobudur.UNESCO.

Cahyandaru N, Arif Gunawan, Arif Widodo. 2008. Analisis Mortar Pemugaran Pertama serta Evaluasi Efektivitas dan Dampaknya. Laporan Kajian Balai Konservasi Peninggalan Borobudur.

Hyvert, G. 1972. The Conservation of the Borobudur Temple (Indonesia). Paris: UNESCO.

Meucci, C. 2007. Candi Borobudur Research Program;

Degradation and Conservation of Stone, UNESCO Expert Mission Report.

Munandar, Aris, dkk. 2011. Pengembangan Mortal Tradisional Sebagai Bahan Grouting, Laporan Percobaan Proyek Penganganan Candi Prambanan Pasca Gempa. Tidak dipublikasikan.

Soekmono. 1976.Chandi Borobudur a Monument of Mankind. Paris: Unesco Press. 